\title{
Higher Education and the Unique Gifts of Persons with Intellectual Disabilities
}

\author{
Anna Nahirna and Olha Mykhailyshyn
}

\begin{abstract}
This chapter gives an overview of the unique experience of the Ukrainian Catholic University, which, with the help of the Emmaus Centre of Support for People with Special Needs, welcomed people with intellectual disabilities into its educational milieu as professors of human relationships.
\end{abstract}

\section{Keywords}

people with intellectual disabilities - Emmaus Centre - Ukraine - human relationships

The mission of higher education should be more than simply transferring knowledge through learning processes. Ideally, an institution, such as university, should become a platform for the transformation of the mind and heart. Enlightening the vision of the future agents of change is, indeed, indispensable to building a more humane society. It is especially vital in those countries which have suffered from decades of oppressive regimes and ideologies. This chapter will cover the experience of the Ukrainian Catholic University (UCU) and the way it transformed post-Soviet prejudices against people with an intellectual disability through the activity of the Emmaus Centre of Support for People with Special Needs. To obtain a more profound understanding of the special role the Emmaus Centre plays at UCU, the chapter will follow a threefold logical sequence. In the first section, we will draw attention to the unique gifts of people with a disability, as articulated in the works of thinkers such as Jean Vanier and Henri Nouwen. The second section will disclose in more detail the fundamental motives behind the presence of people with an intellectual disability in the university milieu and the functioning of the Emmaus Centre.

(C) ANNA NAHIRNA AND OLHA MYKHAILYSHYN, 2021 | DOI: 10.1163/9789004459076_010 
Lastly, we will highlight the activitities of the Emmaus Centre on and off campus, and the impact it has on the formation of the students and university staff.

We are used to being told that weak people need strong people. This is obvious. But inner unity and healing come about when strong people become aware of their need of the weak. The weak awaken and reveal the heart; they awaken energies of tenderness and compassion, kindness and communion. (Vanier, 1997, p. 222)

In 1964, Jean Vanier, ${ }^{1}$ a son of the Governor General of Canada, left behind his professorship at the University of St. Michael's College in Toronto to start a community of L'Arche with two men with intellectual disabilities in TroslyBreuil, France. After he had become aware of thousands of people with developmental disabilities enclosed in psychiatric institutions, he began paying visits to these places to meet them. It was in one such institution that he encountered Raphael and Philippe, in whose eyes Vanier believed to have read the following: "Do you want to become my friend? Do you love me? Will you come back to see me?" (Vanier, 2008, p. 9). Since then, a network of 15 o L'Arche communities were founded around the world in response to the fundamental need from which such questions stem. Yet, as it is hinted in the introductory quote, this need is far from being one-sided: it is, in fact, mutual and entails the discovery and recognition of our common humanity.

While responding to this largely neglected need of people with an intellectual disability to be loved and accepted as everyone else, the assistants living in L'Arche, likewise, become the beneficiaries of the unique gifts reciprocally bestowed on them. Living a community life, where people with developmental disabilities are referred to as 'friends', they enter a process of becoming truly human. "Strangely enough", Vanier writes, "this process of becoming human occurred most profoundly for me when I started living with men and women with intellectual disabilities, people who are not very capable on the intellectual or practical level, but who are very gifted in relationship" (1999, pp. 1-2). When we bypass the barriers of fear and open up to the vulnerable other, we come to the discovery and acceptance of own vulnerability, which, individually and collectively, makes us more human. In acknowledging the mutual nature of vulnerability, we no longer experience it as weakness but rather as strength. It is in this way that encounters with 'friends' awaken our inherent energies of 
tenderness and compassion, which inspirit us to do good and become responsible for one another.

Yet, there is more to their gifts than the power to inspire goodness in others. Essentially, we are brought in touch with our innate goodness in the context of genuine and accepting relationships, which encourage us to reveal our deepest identities. In 1986, a renowned Dutch philosopher and theologian Henri Nouwen followed the steps of Vanier and left his teaching position at Harvard University to permanently move to L'Arche Daybreak community in Ontario, Canada. There he was asked to take care of a young man, Adam, with a severe developmental disability. Nouwen's life with Adam and other 'friends' of the community ushered in some of his most profound reflections on the unconditional sense of love and acceptance he had experienced with them. "After my many years of studying, reflecting, and teaching theology", shared Nouwen, "Adam came into my life, and by his life and his heart he announced to me and summarized all I had ever learned" (Nouwen, 1997). To Nouwen, Adam's fragile presence was witness to the deepest significance of the humanity of everyone else. This significance was unfolding, as Michael Hryniuk notes, through the journey Nouwen was making with Adam: "the journey from the life of the mind to the life of the heart, where a relationship of communion is possible" (Hryniuk, 2010, p. 130). This way, Nouwen's friendship with Adam and other members of L'Arche led to him to the discovery of his true self. "By simply being who they are", he writes, "they break through my sophisticated defenses and demand that I be as open with them as they are with me" (Nouwen, 1999, p. 127). In their disarming sincerity, simplicity and vulnerability, 'friends' help us reveal and cultivate our unconditional self-worth beyond the social hierarchies, competition and comparison.

These gifts of people with an intellectual disability, in a subtle way, attest to our profound need for one another and desire for communion. They bring an alternative perspective on social responsibility in which each human being is to be acknowledged and cared about not by pity, but because they are recognised in their inherent value. Uniquely, by inviting to its milieu those who were unjustly marginalised, and by encouraging ongoing contacts with them, UCU became one of the first educational institutions to nurture this genuine perspective on social responsibility.

\section{From Intellectual Development to Transformation of the Heart: The Mission of 'Friends' and the Emmaus Centre at UCU}

At UCU we do not only care about the intellectual development of the students. That is why we have invited people with special needs to the 
center of our university, those whose place should not be here, according to the common way of thinking. [...] For us they are professors of human relationships. (The Emmaus Centre, 2019)

UCU began to function in 1994 as an agent of change, providing students not only with quality education, but also with an alternative social vision in which people with an intellectual disability play an essential role. It was through Archbishop Borys Gudziak, a Ukrainian American who shared a friendship with Henri Nouwen, that the ideas of L'Arche were brought to Ukraine and UCU. Having become its first rector, Archbishop Gudziak encouraged the realisation of the idea of welcoming people with an intellectual disability to the university campus, so they could become professors of human relationships as mentioned above. "Back in the nineties when we were brainstorming the idea of the university", he shares, "we discovered that people with intellectual disabilities not only have special needs but also special gifts. They are open, without any masks, their presence breaks the systems which hinder communication" (The Emmaus Centre, 2019). Social status and hierarchy are of little importance to them as they communicate primarily at the level of the heart. In the university, where so much attention is drawn to one's intellectual achievements, encounters with people with an intellectual disability are especially vital - they engender trust, put students at ease and help them radiate their innate human dignity. That is why, in recognition of these gifts, 'friends' at UCU are uncommonly seen as those who have a special mission of transforming hearts.

To support people with a disability in this mission and facilitate their integration in the university environment and society, the Emmaus Centre was established in 2001 as an integral part of UCU. It is worth noting that after nearly 70 years of Soviet ideology that stigmatised and discriminated against people with a disability, the newly democratised Ukraine has been facing many challenges to offer a better life to the weakest of its citizens. It was in this difficult context that the Emmaus Centre began its mission of promoting an inclusive society in which every person with an intellectual disability, including the weakest and most vulnerable ones, is valued and accepted. Currently, the activities of the Emmaus Centre reach the furthermost corners of Ukraine and encompass three spheres, namely: (1) awareness raising, (2) family support and (3) socialisation and integration of people with an intellectual disability into society. Yet, the key processes aimed at social transformation begin with the projects at UCU.

One of the most innovative among them is the Emmaus House - an apartment in the student dorm where people with an intellectual disability live with young assistants in a family-like community. Thus, being side by side with the students, 'friends' are given the space to fulfill their above-mentioned mission 
of transforming hearts. Having the Emmaus House as their home after years of difficulties (e.g. suffering from abuse or living in a psychiatric institution), 'friends' too witness a considerable personal transformation. The loving environment of the House and frequent contacts with students, create fertile ground not only for their gifts as professors of relationships to shine forth, but also for their growth as individuals. Over the past years, 'friends' have become more open, confident, and independent, and they have developed their daily routines and hobbies. For example, some 'friends' underwent a transformation from those who were afraid to take a glass of water without unauthorised permission to those who would point out to the students the need to turn off their cellphone while visiting. Their socialisation level, in fact, has already transcended the university community. Recently, one of the residents of the Emmaus House has been employed. His responsible and admiring attitude to work encourages other 'friends' and evokes sincere respect among everyone else. Transformations as these, where the gifts of 'friends' come to light, are stimulated by the positive atmosphere in the Emmaus House and their ongoing interactions with students who participate in the life and events of the community. As a result, by initiating such mutually-transforming interactions, the mission of the Emmaus Center, as Archbishop Gudziak remarks, goes even deeper "to help the modern post-Soviet and postmodern person recognise and radiate their dignity given by God" (The Emmaus Centre, 2019).

It is often said that UCU is built on two 'Ms': the martyrs of the Greek-Catholic Church and people with an intellectual disability. The martyrdom of the latter, often defined by an acute sense of physical and emotional suffering, remains majorly overlooked around the world. For many, their vulnerability and otherness become a source of anxiety. Having put service to 'friends' and those who are weaker at the basis of its strategy, the experience of UCU, on the contrary, illustrates human vulnerability as a source of unity and how in welcoming it we may learn to welcome and embrace otherness in general.

\section{'Being with' as a Source of Genuine Social Responsibility: The Fruit of the Work of the Emmaus Centre at UCU}

Most universities believe that they exist for the sake of academic excellence. We are sure that we exist to serve the people. And that academic excellence is the best way to achieve this. (Стратегія УКУ, 2019, para. 1)

The strategy of the Ukrainian Catholic University for 2020-2025 with a selfrevealing title, "The University that Serves", very clearly and concisely proclaims 
that social responsibility is to begin within its walls with the experience of servitude and 'being with' those who are 'weaker'. Now that scientists predict a rapid increase in the proportion of people with higher education both globally (Projected world population, 2016) and in Ukraine (Lutz et al., 2014), the role of universities in shaping future generations increases dramatically. In fact, since the beginning of the 21st century, the university has not only been a structural element in the educational system, but also an institution of personality formation in all aspects of life, including in the direction of social responsibility. At UCU, this responsibility is carried out by the Emmaus Centre, which takes the following practical directions while working with students:

a. Informative: Disseminating information on people with an intellectual disability in the university environment, in order to assert their existence and overcome prevailing stereotypes. In particular, the representatives of the Emmaus Centre give presentations on how to communicate with 'friends' during formation sessions for students and university staff, 'friends' are involved in the main university events, literature related to disability is published and disseminated, and thematic events and presentations are often held on campus.

b. Communicative: Providing unobtrusive communication with people with a disability to facilitate their positive perception by others and help others acquire basic communication skills with them. To accomplish this task, a series of events are held at UCU, such as Friday Coffee (warm drinks and board games for 'friends' and university staff in the lobby of one of UCU's main buildings), Wish Tree Campaign (fulfilling dreams of certain friends which presuppose interaction), International Culinary Evenings (cooking meals from different national cuisines with students at the Emmaus House), etc. Oftentimes, students themselves initiate various activities to communicate with 'friends', such as movie sessions or singing evenings held in the Emmaus House.

c. Applied: Our centre serves as the base for student volunteering and internships in psychology, social work and social pedagogy.

The work of the Emmaus Center bears fruit. Unfortunately, there has been no generalised sociological research on the impact of its activity on the university community, which of course opens directions for further research. The results below are based on a generalisation of the empirical experience of staff of the Emmaus Centre and feedback of students and staff at the university. Epitomising our perennial experience, we can confidently say that the discovery of the gifts of people with an intellectual disability had an impact on both the individual and institutional formation on three levels: 


\section{- Personal Impact}

The perception of otherness of the neighbor allows one to re-evaluate oneself. Many students and staff noted that although it was difficult to take the first step in building relationships with 'friends', their communication eventually ushered in the precious discovery of a less complicated world. Nadia Kalachova, a PR manager in the Emmaus Centre, shares that when Paul, a young man from the network of 'friends', told her to straighten up, he was not referring to posture, but rather telling her not to hide her heart and be open to people. 'You are simply divine!' he would say to her and thereby help Nadia rediscover her own individual uniqueness (The revolution of tenderness, 2019). Through their encounters with friends, students, in a similar way to Nadia's, get in touch with their true identity. They arrive at a deeper understanding of themselves and their purpose in life, they reassess their value systems, abandon their fears or complexes and become more open to something new. Those who regularly interact with 'friends' increase their level of discipline, responsibility, tolerance and their ability to care for others. Many of the students eventually witness that communicating with people with an intellectual disability gives an understanding of the relativity and conventionality of material things while appreciating true values.

\section{- Communicational Impact}

Internal psychological changes cannot but have an effect on communication. According to the president of UCU, Archbishop Borys Gudziak, this is so "because relationships are the matrix of our life" (Гудзяк, 2020, para. 3). Tolerance is a reflexive feeling. We are not simply tolerant within ourselves, but first and foremost regarding a phenomenon or person. The deepening of tolerance in all its manifestations helps us understand the needs of the interlocutor better, to get into their position. In addition to the everyday context, changing the quality of communication also has an economic dimension, namely, in terms of customer orientation. This could clearly be observed during the Socially Ingenious Weekend, organised jointly with the representatives of Thomas More Kempen (Belgium). Over the weekend, students of IT and social pedagogy had to work out a prototype of a technical solution or software that would make it easier for a person with special needs to complete tasks like buying and paying in the supermarket. And it was primarily via communication that specific needs of 'friends' were identified. In this context, little does it matter whether the customer has a disability or not - each client has their own needs and vision. It should be noted, in fact, that some IT students discovered social work as a niche for IT practice, which is now primarily business oriented. 


\section{- Structural Impact}

The activities of the Emmaus Centre in the institution with a high concentration of intelligence is, indeed, a unique phenomenon for the academic environment. UCU is the first university to begin positioning itself as a university that serves, an agent of change in non-academic fields. The effectiveness of the Emmaus Centre contributes to the fulfillment of the university's mission and its worthy results confirm the accuracy of the path UCU has taken. Such positive innovations, as the establishment of the Emmaus Centre, have found their international support. As the president of the University of Notre Dame John I. Jenkins noted during his visit to UCU, "the aspiration of Catholic education is not simply the importing of knowledge and skills, but the transformation of lives and ultimately the healing of a broken world" (Corcoran, 2019a, para. 2). "It was an inspiration for me" (Corcoran, 2019b, para. 7), said Jenkins of the Emmaus House.

By integrating the Emmaus Centre into its structure, UCU provides muchneeded help for people with an intellectual disability in society. Without the support of UCU, it would undoubtedly be much more difficult for the Emmaus Center to function and spread its vision even in those areas of activity that are not directly related to the university. Being an atypical part of UCU, however, the Emmaus Centre shifts the focus of university activity from purely academic to socially responsible, helping to nurture not only intellectuals but also the morally conscious elite for our society.

\section{$5 \quad$ Conclusion}

In today's world we often tend to alienate ourselves from the otherness and vulnerability of the neighbor. As a consequence, this alienation extends to our sense of social responsibility - much is being done for the others without the genuine knowledge of their needs. In this context, the experience of the Ukrainian Catholic University gives a unique perspective on social responsibility, which entails the experience of 'being with' those who are 'weaker' and thereby finding our common humanity. In learning to welcome the vulnerability of 'friends', we, likewise, learn to welcome our own vulnerability and come to the roots of what is common for us all, whatever our culture, faith or gifts. The recognition of our common humanity engenders the recognition of the value and beauty of each human being, which via the academia, can be witnessed to the rest of the world. 


\section{Note}

1 Soon after this contribution had been written, the reputation of Jean Vanier came under a cloud with the discovery of his involvement in the sexual abuse of several women without disabilities. The following is the link to the official report made by L'Arche International: https://www.larche.org/documents/10181/2539004/Inquiry-Summary_Report-Final-202O_O2_ 22-EN.pdf/6f25e92c-35fe-44e8-a8ob-dd79ede474. As authors of this contribution, we perceive it as our duty to notify the reader of this unfortunate news to avoid any misunderstandings. Yet, however incomprehensible this news is, it does not undo all the good Vanier's inspiration did for people with an intellectual disability around the world.

\section{References}

Cmpamezir [Bogdan, P.]. (2019). УКУ на 2020-2015 роки [Ukrainian Catholic University Strategy 2015-2020]. https://s3-eu-central-1.amazonaws.com/ucu.edu.ua/ wpcontent/uploads/2020/o1/Strategiya-2025-final-27.19.pdf

Corcoran, K. (2019a). Archbishop Borys Gudziak receives 2019 Notre Dame Award. https://www.nd.edu/stories/notre-dame-award-2019/

Corcoran, K. (2019b). The professors. https://www.nd.edu/stories/the-professors/

Гудзяк, Б. [Gudziak, В.]. (2о2о). Сила вдячності [The power of gratitude]. https://nv.ua/ukr/opinion/intujiciya-strah-rozgublenist-u-chomu-sila-lyudiniboris-gudzyak-50062951.html

Hryniuk, M. (2010). Growth in communion: A phenomenological perspective. Theology, Disability and Spiritual Transformation: Learning from the Communities of L'Arche. Cambria Press.

Nouwen, H. (1997). Adam's hidden life. In Adam: God's beloved. Orbis Books.

Nouwen, H. (1999). Epilogue: Living the painting. In The return of the prodigal son: A story of homecoming. Continuum.

Lutz, W., William, P., \& Samir, K. C. (2014). World population and human capital in the twenty-first century. Oxford University Press.

Projected World Population by Level of Education. (2016). Webpage.

https://ourworldindata.org/grapher/projection-of-world-population-ssp2-iiasa

The Emmaus Centre. (2019). Who we are. https://emaus.ucu.edu.ua/en/who-are-we/

Vanier, J. (1997). Choosing peace. In Our journey home: Rediscovering a common humanity beyond our differences. Hodder and Stoughton.

Vanier, J. (1999). Introduction. In Becoming human. Longman and Todd Ltd.

Vanier, J. (2008). Part I: 1964-1969, Beginnings at Trosly: A good earth. In Our life together: A memoir in letters. Longman and Todd Ltd. 